NBER WORKING PAPER SERIES

\title{
ISSUES AND RESULTS FROM RESEARCH ON THE ELDERLY I: ECONOMIC STATUS \\ (PART I OF III)
}

Michae1 D. Hurd

Working Paper No. 3018

\author{
NATIONAL BUREAU OF ECONOMIC RESEARCH \\ 1050 Massachusetts Avenue \\ Cambridge, MA 02138 \\ June 1989
}

Support from the National Institute on Aging is gratefully acknowledged. Many thanks to Karen van Nuys and Duke Wang for research assistance. This paper is part of NBER's research program in Aging. Any opinions expressed are those of the author not those of the National Bureau of Economic Research. 
NBER Working Paper \#3018

June 1989

ISSUES AND RESULTS FORM RESEARCH ON THE ELDERLY I: ECONOMIC STATUS (PART I OF III PARTS)

\section{ABSTRACT}

This is the first part of a three-part paper on research on the elderly. The objective of the paper is to present issues and research results in three areas: economic status, retirement, and consumption and saving. This part covers background material on demographic change, living arrangements, income growth and labor force participation, and research on economic status.

The major areas of research on economic status are: adjustments to observed income to bring it closer to a welfare measure with the objective of understanding whether the elderly are better off than the nonelderly; the distribution of income among the elderly and in particular the extent and causes of the high poverty level of elderly widows; wealth holdings, especially sources of wealth and the importance of public programs.

Michael D. Hurd Department of Economics SUNY

Stony Brook, NY 11794 


\section{Introduction}

Research by economists on the elderly has grown rapidly since the 1978 review on the economics of aging in this Journal (Robert Clark, Juanita Kreps and Joseph Spengler, 1978). An important reason for this growth is demographic change. In 1900 just 48 of the population was elderly ( 65 or older). By 1980 the elderly were 118 of the population and they are projected to rise to 22 in 2040. Although each age group has its own productive capacities and demands, the capacities and demands of the elderly are very different from the rest of the population, so the large demographic changes will have a substantial impact on society. For example, because few elderly work, their consumption must be financed either through their own savings or through social programs: The demographic changes are bound to put stress on capital markets and social institutions. Each age group faces uncertainty, but the consequences of uncertainty for the elderly are probably larger than for other age groups simply because they have fewer remaining years over which to spread windfall gains or losses. Furthermore, they have fewer responses to unexpected events. For example, many retired elderly cannot return to the work force in response to an unanticipated drop in income.

A second reason for the increase in research on the elderly has been the availability of data that can be used to study and test some basic economic models. Retirement is an aspect of labor supply. The Social Security system and pensions offer economic incentives that are different from the labor market incentives offered earlier in life. The response of workers of retirement age can provide information about the tradeoff between goods and leisure which can complement knowledge gained from studying the labor supply of younger workers.

The study of the consumption behavior of workers has been difficult because their main asset, human capital, is not observed. The main assets of the 
retired elderly (financial assets, housing and claims on retirement programs), however, are observed. Study is further simplified because the utility of retired individuals only depends on consumption, whereas the utility of workers depends on consumption and leisure. Therefore, only the intertemporal aspects of utility maximization need to be considered, not the intratemporal aspects. In 1 ife cycle models, consumption depends on the interest rate and on mortality rates, as well as on assets. But variation in interest rates across individuals is typically not observed, and, among younger people, variation in mortality rates from person to person is so small that any effect is absorbed in the constant parameters of a consumption model. The mortality rates of the elderly are substantial, and they vary considerably by age and by sex. The variation can econometrically identify important utility function parameters.

The demographic changes and the research questions would have attracted much less attention, however, had it not been for the Retirement History Survey (RHS). THE RHS is a ten-year longitudinal survey of 11,153 households whose heads who were 58-63 in 1969. Every two years the heads (or their spouses if the head had died) were questioned about income, assets, employment, health, and social and family interactions. Most importantly, the official Social Security earnings records were attached to the survey data. From them, each person's Social Security eligibility and benefits can be calculated exactly. In principle, this provides the necessary data to estimate the effects of Social Security on retirement. The earnings records can also be used to form a good estimate of lifetime earnings, which is almost necessary in any study of lifetime wealth accumulation. The RHS has proven to be an invaluable resource: many results to be discussed in this paper are derived from the RHS data.

The main goal of this paper is to present and analyze some major research questions and findings. The research falls in three main areas: economic status of the elderly, retirement, and consumption and saving behavior. Health, 
which is properly the subject of an entire paper, and social and family relationships are only mentioned in connection with the topics covered.

Because the analysis will often refer to recent economic and demographic changes, the next section will use widely available data on population, life expectancy, living arrangements, labor force participation, and income to provide background for the discussion of the research.

2. Demographic and Economic Changes.

Between 1900 and 1980 the proportion of the population that was elderly increased from 48 to 118 (Table 1). The proportion 85 and over increased from a fraction of a percent to 18 , which is about 2 million people. Population forecasts, which should be quite accurate over the next 30 years, show large increases in the fraction of the population that is old. By 2050, 68 (16 million people) of the population will be 85 or over; about eight million people will be 90 or over. Thus between 1980 and 2050 the number aged 85 and over is expected to increase by a factor of eight.

Part of the change in the age distribution is due to a long-term fall in birth rates, which, by itself, would have gradually increased the average age Part of the large projected increase in the elderly is due to the baby-boom cohort (1946 to 1964). The fattest part of this bulge in the population will be 65 in 2020 and 95 in 2050. Mortality rates have fallen sharply, contributing to the change in age distribution: in 1900 life expectancy at birth of males and females was 46 and 49 years respectively; in 1980 it was 70 and 78 .

Life expectancy, conditional on reaching 65 , is forecast to continue to increase (Table 2). If there is no change in the average retirement age, the fraction of life spent in retirement will increase. Financing more consumption from a shorter worklife will strain the savings of each retired person. The 
problem for society is greater because the probability that an individual will reach 65 will continue to increase and the number of individuals in the cohorts approaching 65 will rise. Therefore, the fraction of output consumed by the retired will increase substantially. This will affect not only social Security and private pensions but capital markets as the retired convert their savings into consumption.

At the turn of the century, the conditional life expectancies of men and women were practically the same. By 1980 a 65 year-old woman could expect to live 4.2 years more than a 65 year-old man. The difference is forecast to continue to increase slowly. Beyond the more obvious impacts on Social Security and pensions, the differences in life expectancy mean that most of the very old are widows. Because the very old must finance a long lifetime of consumption, it is likely that they will have few assets toward the end of their lives. Therefore, in the absence of social programs, the longer lifetimes of women will lead to high rates of poverty among widows. As will be discussed below, elderly widows have substantially higher poverty rates than others; the population forecasts give no suggestion that demographic changes by themselves will reduce the rates.

Higher mortality rates of men affect the living arrangements of the elderly. In 1985,538 of the elderly lived with a spouse, but the distribution was very different for men and women: 758 of elderly men lived with their wives while only 388 of elderly women lived with their husbands (Table 3 ). 1

Differences in living arrangements by age were much smaller among men than among women because most wives outlive their husbands. For example, 498 of women aged 65-74 lived with their spouses compared with 238 of women aged $75+$. Most of the women not living with spouses would be widows. Of that group about two-thirds lived alone. Comparisons over time show a small increase in the fraction of elderly men living with a spouse (probably due to the increase in the life 
expectancy of women), and a modest increase in the fraction living alone. Among women the changes were much greater: 248 lived alone 1960,418 in 1985 . The fraction living with relatives fell from 348 to 188 . The largest changes were among women 75 and over: during the 25 years the fraction living alone almost doubled from 268 to 508 ; the fraction living with relatives fell from 468 to 258. The trend from living with relatives to living alone was due, at least partly, to rising economic resources (Robert Michael, Victor Fuchs and Sharon Scott, 1980; Karen Holden, 1986; Saul Schwartz, Sheldon Danziger and Eugene Smolensky, 1984). If incomes are stable in the future, a continuing increase in the difference in life expectancies, as forecast in Table 3 , implies that about half of elderly women will live alone.

The average real income of the elderly, as conventionally measured in the Current Population Survey, increased by about 298 between 1970 and 1986 (Table 4), with more than half of the increase coming between 1970 and 1975. The mean income of the entire population increased by only 8.58 , so that the income of the the elderly relative to the entire population rose from 0.54 to 0.64 . As will be discussed below, this income measure is far from what economists would call a full income measure, and it makes no provision for differences in household size. Nonetheless, the figures give a good indication of the relative income gain of the elderly.

The income growth of the elderly was accompanied by rather large changes in the source of income as shown in Table 5. Income from earnings fell from 298 of total income in 1967 to 178 in 1986. The fraction of income from Social Security and pensions increased from 498 to 548 , mostly due to increases in Social Security. Income from assets increased substantially but, as to be discussed below, assets are so highly concentrated that the change was not important for many of the elderly

Table 6 gives the distribution of elderly households according to the 
fraction of each household's income from various sources. For example, in 1971 , 698 of elderly households had no earnings, 168 had from 18 to 498 of their income from earnings, and 158 had 508 to 1008 of their income from earnings. The table shows that by 1986,818 of elderly households had no income from earnings, and that just 88 had more than half of their income from earnings. (a2

The percentage of households having no income from Social security dropped from 138 in 1971 to 88 in 1986 . This change is partly due to increasing coverage of Social Security. It is also due to earlier retirement: under the Social Security law, few full-time workers would receive Social Security benefits, so as participation rates fell, the fraction receiving Social security benefits rose. The importance of Social security to most elderly can hardly be overstated: in 1986578 had more than half of their income from social Security, and 248 had more than 908 .

Although the fraction of the elderly with income from public and private pensions and annuities (almost all pensions) has increased, pensions are still a modest source of income. In 1986, only 268 had private pension income; about 138 had government pensions. These figures imply that, at most, 398 of households had some pension income. Even among those with pension income, few households had a large fraction of their income from pensions: just 78 of households had more than 508 of their income from either private or public pensions. Again, 578 of households had more than half of their income from Social Security.

Table 6 confirms that asset income (which does not include any imputed income to housing equity) has become more important; yet, in 1986408 of households had no income from assets, and 708 of households had less than 208 of their income from assets. These figures accord with findings to be reported later that many households retire with practically no financial savings. Although asset income was 268 of total income (Table 5), most households had 
small amounts from assets, reflecting the highly skewed distribution of wealth.

The decrease in the importance of earnings is reflected in changes in labor force participation, which for the elderly, is practically synonymous with retirement. The changes in participation are large: between 1950 and 1987 the participation rate of elderly men fell from 468 to 168 . In comparison, the participation rate of the population increase from 608 to 668 , due to increased participation by women. The fall in participation has been greatest at the most advanced ages, but even at younger ages it has been substantial (Table 7). For example, the participation rate of men $55-59$ fell between 1957 and 1987 from 91.48 to 79.78

The normal retirement age of men, which at one time was 65 or even older, is now less than 65 Many men retire in their late 50's. Among women two opposite trends, earlier retirement and higher lifetime participation rates, have kept the participation rates of 60-64 and 65-69 years olds approximately constant. A way to isolate the trend to earlier retirement is to calculate the retirement hazard rate, which is the probability of retirement at age $T$ given labor force participation at age $T-1$. A rough calculation of the retirement hazard rate can be made from the participation rates of Table 7 by assuming that the cross-section participation probabilities are the same as the participation probabilities as an individual ages.

\section{Retirement Hazard Rates}

\begin{tabular}{ccccc} 
& \multicolumn{2}{c}{ Wen } & \multicolumn{2}{c}{ Women } \\
$\frac{\text { Year }}{1957}$ & $55-59$ to & $60-64$ to & $55-59$ to & $60-64$ to \\
1987 & $\frac{60-64}{.093}$ & $\frac{65-69}{.366}$ & $\frac{60-64}{.207}$ & $\frac{65-69}{.422}$ \\
& .311 & .530 & .364 & .569
\end{tabular}


Source: Author's calculations based on Table 7

According to this method of calculation, in 1957 the probability of retiring at ages 60-64 given labor force participation at ages $55-59$ was 0.093 for men and 0.207 for women. Thus, even among the small number of women who were in the labor force later in life the retirement probabilities were higher than the retirement probabilities of men. The retirement hazards of men increased more so that by 1987 the hazards of men and women were about the same.

The data discussed in this section show large changes in the demographic structure of the population, and in the income, labor force participation, and living arrangements of the elderly. Some of the research to be reviewed in the rest of the paper will aim at understanding the consequences of these changes, and some will aim at learning the causes of the changes.

\section{Economic Status}

The broad goals of the research on economic status have been to find better measures of economic well-being than simple income statistics, and to use the measures to determine whether the economic status of the elderly has improved over time, whether it has improved faster than the economic status of the nonelderly, and whether it is higher than the economic status of the nonelderly. The ultimate social usefulness of the work is to assess whether the system of transfers from the nonelderly to the elderly is adequate. Broadly speaking, the work has immediate policy implications. For example, it could be used to help decide how much of the rising Medicare and Medicaid costs should be borne by the elderly and how much by the nonelderly.

Some of the research is concerned with measurement: how to impute income flows from nonmoney sources such as housing, and Medicare and Medicaid, and how 
to adjust for taxes and underreporting of income. Other research aims to find welfare measures from income: how to adjust for family size and composition to account for need. Considerable work has been aimed at distributional aspects of income, in particular, at poverty. Some work has been done on wealth measures of well being, but limitations of data and comparability with the nonelderly limit its application. ${ }^{3}$

\subsection{Trends in Income}

No single study has an income series with all the household size adjustments and adjustments to income that are desired. Therefore, I first give results that are based on the consistent application of one particular size adjustment. The similarity of method over years should increase our confidence in the observed trends. Then, I give results for a single year that incorporate all the adjustments. Provided there is stability of the effects of the adjustments, the two approaches taken together should give a good idea of the fully adjusted trends.

Table 8 shows annual growth rates in income and the level of income in 1984 adjusted for household size according to the official poverty index. ${ }^{4}$ In this scaling, one nonelderly person has a weight of 1.024 , two nonelderly persons 1.322 , three persons (either elderly or nonelderly) 1.568 and so forth. 5 Elderly persons are given slightly smaller weights (about 88 smaller than the nonelderly). Size-adjusted income (income per equivalent person) is household income divided by the household weight. The scaling embodies the assumption of substantial returns to scale in household consumption: a two-person nonelderly household requires only 298 more income than a one-person household. This scaling yields income measures that are closer to income per household than to income per person: income per household has an implicit weight of 1.0 for all 
households whereas income per person is based on assigning a weight of 1.0 to each person.

The average elderly family unit is smaller than the average nonelderly family unit ( 1.7 persons per household versus 3.0 persons in 1980), so the size adjustments will raise the income measure of the elderly relative to the nonelderly. In Table 8 the ratio of incomes of the nonelderly to the elderly was 0.67 in 1984 with no size adjustment; the ratio was 0.87 with the size adjustment. Average family size has decreased over time, but it has decreased more for the nonelderly than for the elderly. Therefore, the size adjustment will produce a larger increase in income per equivalent person of the nonelderly than of the elderly. For example, the size adjustment increased the annual rate of growth of income between 1979 and 1984 by 0.98 for the nonelderly but by just 0.38 for the elderly.

By either the unadjusted or adjusted income measure the elderly had much higher rates of growth of income than the nonelderly. These differences cumulate over a number of years to give quite different income changes. For example the total income changes from 1967 to 1984 are

\section{No size adjustment size adjustment}

$\begin{array}{lll}\text { Nonelderly } & 10.78 & 26.78 \\ \text { Elderly } & 42.48 & 54.78\end{array}$

Source: Table 8

The growth of income of the nonelderly has come from increased work effort, 6 whereas earnings of the elderly have fallen as their labor force participation rates declined.

Table 8 shows that, after adjusting for size, in most cases income growth 
increased with age. This is partly due to the aging of younger, more wealthy cohorts and partly due to increases in Social Security, which are relatively more important to the very old. Still, as measured in Table 8, by 1984 the incomes of the most elderly were still lower than the incomes of any age group. Table 9 indicates that incomes of the elderly increased throughout the income distribution. ${ }^{7}$ In the second decile their incomes grew rapidly during the first time period, possibly due to large across-the-board increases in Social Security benefits. They continued to grow in the second time period, although at a slower rate. Total growth over both periods was about 848 . The nonelderly in the second decile had much less growth during the first period, and their incomes fell substantially during the second period. The difference in the experience of the nonelderly and the elderly is clearly shown by the sharp break in growth rates at ages 60-64. Total income growth of the nonelderly over both periods was very close to zero.

The elderly in the ninth decile had consistent income growth, but overall (1967-1984) it was less than the elderly in the second decile: 498 compared with 848 . The nonelderly in the ninth percentile also had income growth over both periods, and, although there were some differences in each period, total growth was not much different from the income growth of the elderly in the ninth decile. It was much different, however, from the income growth of the nonelderly in the second decile.

The general impression from the table is that the poorer elderly have done much better than the poorer nonelderly, especially between 1979 and 1984 . Incomes of the well-to-do elderly have increased sharply in recent years. probably due to the increase in asset income noted in Tables 5 and 6 . Between 1969 and 1984 income inequality among the nonelderly seems to have increased, particularly from 1979 to 1984. From 1969 to 1984 income inequality among the elderly probably decreased, but not from 1979 to 1984 . 
The income growth in Tables 8 and 9 include cohort effects: changes within an age group are not those of any individual or group. The following table roughly eliminates cohort effects by giving the income (1982\$) of the cohort born in $1898-1903$.

Year and Age

$$
1967 ; 65-69
$$$$
1979 ; 75-79
$$$$
1984 ; 80-84
$$

\section{Mean Income}

11,095

10,847

11,469

\section{Median Income}

7,810

7,807

7,843

Source: Radner, 1986.

In 1967, when this cohort was 65-69 years old, its mean real income was $\$ 11,095$; in 1979, when it was 75-79 years old, its mean real income was $\$ 10,847$. Some may find the stability of income surprising in view of the high rates of inflation during the 1970's. At one time it was generally thought that the elderly live on fixed incomes and are vulnerable to inflation; but these figures suggest the income of the elderly is effectively indexed.

The stability between 1967 and 1979 is not a reliable indicator of income indexing because of two countervailing changes: earnings would have dropped because of the trend toward earlier retirement; Social security benefits would have increased due to changes in the benefit schedule in the early part of the 1970's. However, the stability between 1979 and 1984 , when the CPI increased by 438, certainly indicates effective indexing. 8 Just why income should be effectively indexed is not apparent from the distribution of income by source shown in Table 5. At least part of pension income and part of asset income are not indexed, so that total income is not completely indexed. Detailed study of income in the RHS, however, confirms that incomes of individuals were stable 
during the 1970s, a period of high and variable inflation (Burkhauser, Holden and Feaster, 1988). Apparently the unindexed parts of income were small and concentrated among a few individuals.

A different method of finding inflation vulnerability is based on how the value of assets (including the present value of income flows such as Social Security) is expected to change when inflation changes (Hurd and Shoven, 1985). For example, long-term nominal bonds are vulnerable to changes in the inflation rate whereas housing wealth is not. According to this measure of inflation vulnerability, very few of the elderly would be affected substantially by a change in inflation. This implies that the real value of the income flows from the assets will not change with changes in inflation, which is consistent with the effective indexing of income in the table.

\subsection{Income comparisons.}

The aim of the research on income comparisons is to understand better the economic status of the elderly compared with the nonelderly. Its method is to bring income measures closer to welfare measures by adjusting income for nonmoney components, underreporting and taxes, and by scaling for family size.

Table 10 shows the ratio of average income of the elderly to the nonelderly. for several different income measures and for several size adjustments. Conventional income is the usual income measure from the Current Population Surveys; according to conventional income elderly households had just 528 of the income of nonelderly households in 1971. Line B shows income adjusted for the value of in-kind transfers, implicit income from housing, employment-related benefits and direct taxes. These changes are important. In-kind transfers increased the incomes of the elderly by $\$ 1430$ per household, $\$ 1344$ of which is the market value of the transfers they receive on average through the Medicare 
and Medicaid programs. The elderly have lower tax rates than the nonelderly. even holding income constant. They hold more housing equity. The effect of all these adjustments is to increase incomes of the elderly by about 128 . The most important changes for the nonelderly are taxes, and work-related benefits. These changes decrease average income by 108 . As a result, as shown in 1 ine $B$, the ratio of household incomes increases to 0.65 .

Adjusted income in Table 10 differs from income in two ways. The most important difference is due to underreporting of income: according to a validation study of survey data, the nonelderly underreport on average by about 38, but the elderly underreport by about 378, mainly property income (Radner, 1983).9 This adjustment, which is done for each income source at the household level, substantially increases the income ratios. The other adjustment changes the method of valuing the nonmoney transfers in line $B$ : they are valued at an estimate of what the recipient would be willing to pay for them (recipient value), rather than at the cost to the provider (market value). The recipient value is less than the market value especially for the poor. This adjustment lowers the income ratio due to the large transfers through the Medicare/Medicaid system, but the change is minor compared with the change for income underreporting.

The table has three different adjustments to household income for household size and composition. The aim is to bring household income closer to an individual welfare measure by dividing income by a suitable index. The index used in calculating per capita income is, of course, just the number of people in the household. It embodies the assumption that there are no returns to scale in household consumption. The poverty line index is based on the poverty scale; it was used in the size adjustments in Table 8 . It implies substantial returns to scale: according to this index, if a single elderly male has a consumption weight of 1.0, a husband and wife have a consumption weight of 1.26 . That is, 
the couple would be deemed to be as well off as the single male if their income was 26 greater. The budget share index was estimated from observed variation in consumption patterns as family composition varied in the 1972-73 Consumer Expenditure Survey (van der Gaag and Smolensky, 1982). At least conceptually this is the best of the indices of household size. Compared with the poverty scale it has more modest returns to scale in consumption: according to this index an elderly husband and wife need about 37 more income than a single male.

In my view line $B$ is a better income-based measure of welfare because it is more inclusive. In principle, adjusted income is superior to income, although the adjustment for underreporting only makes sense on average: the underreporting is mainly associated with property income which is highly concentrated. As a rough welfare measure, household income is too high, as it implies it is costless to add additional individuals to a household. Per capita income is too low because it bars any returns to scale. The poverty line index is not based on any observed behavior or theoretical model. That leaves the budget share measure. The income and adjusted-income ratios are 1.04 and 1.28 respectively, implying that in 1979 the elderly were at least as well off on average as the nonelderly, and possibly better off.

The results in Table 10, which are based on detailed analysis of 1979 CPS data, can be updated by applying the observed growth in CPS income. According to the CPS, the ratio of mean incomes of the elderly to the nonelderly increased by 12.38 between 1979 and 1986. If all the components and adjustments to income of Table $10 \mathrm{grew}$ at the same relative rate, the income ratio would grow from 1.04 to 1.17 and the adjusted-income ratio from 1.28 to 1.44 .

Most researcher would agree, I believe, that on average the elderly are at least as well off as the nonelderly as measured by income, ${ }^{10}$ but, as the entries in Table 10 suggest, the magnitude of the differential is not precisely measured. From the point of view of public policy, however, precision is not 
required: if the elderly are as well off as the nonelderly, there is little reason for new policy that would transfer income to them. Policy should concentrate on the distribution of income among the elderly.

\subsection{Distribution of Income.}

Even though Social Security is an important source of income and it acts strongly to reduce income inequality through the progressivity of the schedule from lifetime earnings to benefits, income of the elderly appears to be more unequally distributed than income of the nonelderly. Table 11 has Gini coefficients of income and the percentage of income to the highest income quintile. Although there is some variation by year, data set and income measure, both inequality measures show more income inequality among the elderly than among the nonelderly. The results from the 1973 Consumer Expenditure Survey and the 1979 CPS (unadjusted) are based on the same income measure and they yield about the same Gini coefficients. The adjustments to income in the 1979 CPS reduce income inequality because the well-to-do have higher tax rates and the poor receive a larger fraction of their budgets from nonmoney transfers. The differences between the unadjusted and adjusted inequality measures are greatest among the elderly because of the importance of Medicare and Medicaid. The last three lines are based on consistent methods of measuring income in the CPS: they embody the poverty scale size adjustment for household size discussed earlier. They verify increasing inequality from 1979 to 1984 especially among the nonelderly, as was found in Table 9 .

Income levels, sources of income and the changes in income by source are very different for the highest and lowest quintiles. Table 12 shows that the lowest quintile had about $8 \%$ of the income of the highest quintile in 1967; about 138 in 1979 and 128 in 1984.11 Earnings in the lowest quintile were 
negligible. For this group, Social Security benefits were the only important source of income, and benefit increases were the main reason for increasing income: of the $\$ 1870$ change in real income between 1967 and 1984,818 was due to increases in Social Security benefits. Real earnings of the highest quintile fell over the 17-year period, but the other components of income increased sharply. Social Security benefits increased by a factor of 2.5 , which is a higher rate than the rate of the lowest quintile. The category "Other" is, for the highest quintile, mostly pensions.

The growth in Social Security benefits, especially between 1967 and 1973 , is at least partly due to an upward shift in the benefit schedule, partly to earlier retirement (which causes a shift in income from earnings to Social Security benefits), and partly to increasing lifetime contributions of each cohort. Table 13 gives Social Security benefits of the cohort born in 1893-1897 which, except for mortality, holds constant lifetime earnings. Because most people had retired by age 70 , it also eliminates much of the retirement effect on benefits. Thus, most of the change will be due to changes in the benefit schedule.

Between 1967 and January, 1972 the benefit schedule was changed to increase benefits by 438 holding lifetime earnings constant. A further increase in September, 1972 raised the total change from 1967 to 728 . Total inflation over the period was about $25 \%$. In Table 13 mean real benefits increased by about $36 \%$ ( 38 z for the fifth decile) between 1967 and 1972, which is consistent with the changes in the benefit schedule. Following the increase in 1972, benefits have been indexed, so any increases in average benefits after retirement come from compositional effects. (For example, the poor die sooner than the well-to-do, so average benefits will rise with age.) The table shows, again, the importance of Social Security benefits, especially for the very elderly: in 1982 they were 708 of the income of $85-89$ year-olds. 
The poverty rate of the elderly is an aspect of income distribution that has been the object of considerable study probably because until recently it has been high and because poverty is especially troubling for the elderly. They have few ways to recover from a loss of income, so a fall into poverty tends to be permanent.

The poverty rate is the fraction of a population whose incomes fall below the poverty line, which varies by age and household composition. The poverty line for a single elderly person was $\$ 5,447$ in 1987 ; it was $\$ 6,871$ for an elderly couple. I suspect that most people would regard the poverty line as low indeed, and that someone with income substantially above the poverty line is still poor.

Table 14 shows that, in line with the increases in income, the poverty rates of the elderly have declined sharply. By 1984 they were lower than the poverty rates of the nonelderly, and they remained lower through 1987.12 As reference to Table 12 shows, the Social Security system can claim a major role in the rather remarkable reduction of poverty among the elderly. The decline was largest for the oldest. Yet their poverty rate remains high for reasons connected with widowhood, as will be discussed below.

Putting a value on nonmoney income transfers increases income measures of the elderly considerably, which should lead to a large reduction in poverty rates. The following table shows that to be the case. 
Poverty Rates in 1979, percent

Household

Money Income plus

food and housing

Household

Age Money Income

$<65$

$65+$
10.6

14.7
Market Recipient

8.9

9.0

12.9
Household

Money Income plus

food, housing and medical

Market Recipient

$\begin{array}{ll}6.7 & 8.3\end{array}$

$4.5 \quad 7.0$

Source: Smeeding, 1982

The table has poverty rates by age for various income measures. ${ }^{13}$ The market measure values nonmoney transfers at cost; the recipient measure values them at an estimate of their value to the recipient. ${ }^{14}$ Including food and housing transfers in income reduces poverty modestly for both elderly and nonelderly. Due to the size of Medicare and Medicaid, however, including medical transfers has a large effect: if medical transfers are valued at market cost, the poverty rate of the elderly was 4.58 in 1979. In my view, the size of the transfer is so large (about $\$ 1,344$ in 1979 dollars), especially in relation to the income levels of the poor elderly, that any poverty rates based on augmented income are bound to be only suggestive. ${ }^{15}$ Nonetheless, the implicit transfers in the Medicare and Medicaid program are large and certainly they are of value to the poor elderly. The transfers have continued to grow much faster than the rate of inflation (they grew by about 368 in real terms between 1979 and 1984), suggesting that the poverty rates of the elderly in Table 14, which were already below the poverty rates of the nonelderly, would be substantially below following some adjustment for nonmoney income transfers.

The poverty rate of elderly widows has also declined, but it remains considerably higher than the poverty rates of the population and of the rest of the elderly. Some of the poverty is undoubtedly due to the high fraction of the 
very elderly that are widows: cet.par, one would expect the very elderly to be poor simply because they must finance a longer lifetime of consumption from a given lifetime wealth. Table 15 shows, however, that the explanation is more complicated. It is true that widows aged 72 and over had higher poverty rates than widows aged $65-71$; but younger widows had poverty rates at least as high. One explanation is differential mortality by income level: husbands in poor families die sooner than husbands in well-to-do families. For example, in the RHS the poverty rate in 1969 of couples who survived intact during the entire ten years of the RHS was 7.68. The poverty rate in 1969 of couples in which the husband eventually died during the ten years of the RHS was $11.7 \%$ (Holden, Burkhauser and Myers, 1986). One might think the difference in poverty rates is caused by health expenditures in the several years before the husband's death; but the association with poverty in 1969 and eventual widowhood lasts over many years. For example, the poverty rate in 1969 of couples in which the husband died between 1977 and 1979 was 9.28, again compared with 7.68 for couples intact between 1969 and 1979.

Mortality rates are also associated with wealth levels (Table 16). Couples in the 1977 RHS were divided into two groups: those who survived intact between 1977 and 1979 (surviving couples) and those in which the husband died between 1977 and 1979 (widowed couples). The table gives median wealth in each of the six RHS surveys (covering the years 1969 to 1979) by that classification. All the wealth categories show that the surviving couples had higher wealth than the widowed couples as early as 1969, more than eight years before the husband died. 16 These results imply that the widowed couple would have had fewer assets had the husband survived, and, therefore, would have had a higher probability of being in poverty. 17 The causes of the differential mortality are not known, but there is some indication that lifetime health differences play a role. Table 16 shows that Social Security wealth and pension wealth, both of which are 
good summaries of lifetime earnings, were higher for the surviving couples. ${ }^{18}$ This suggests that lifetime health differences affect both lifetime earnings and mortality rates after retirement, causing the observed correlation.

Beyond differential mortality the transition to widowhood itself seems to induce poverty. Table 17 gives poverty rates by marital transition between 1975 and 1977 for the entire sample of 1975 couples and for the 1975 couples not in poverty in 1975. The table shows that widowed couples (1975-1977) had somewhat but not greatly higher poverty rates than the other couples in the years before the husbands died. However, in the first survey year after the husbands deaths the poverty rate of the surviving widows rose to 428 while the poverty rate of the intact couples was just 78 . Other calculations (not given here) show that the average increase in poverty following widowhood was 30\%. The increase is partly due to income mismeasurement associated with the husband's death (Burkhauser, Holden and Myers, 1986), but mostly due to permanent changes in economic resources as shown by the high poverty rate in 1979 . The two righthand columns give poverty of couples that were above the poverty line in 1975 . 378 of the surviving widows, none of whom had been in poverty in 1975, were in poverty in 1977.

One might well imagine that much of the increase in poverty at the husband's death is due to the termination of his earnings. Apparently, however, this is not the case: using RHS data Burkhauser, Holden and Feaster (1988) studied the determinants of the hazard of poverty of widows, the probability of entering poverty among those not already in poverty. Only 10.18 of the transitions into poverty were associated with the loss of the husband's earnings. About two-thirds of the cases were associated with widowhood itself and with a decline in nonwage income, particularly Social Security. Even after the husband's retirement (so that he had no earnings), the probability of a transition into poverty when the husband dies is high (Holden, Burkhauser and 
Feaster, 1988)

Changes in the components of wealth at the husband's death provide some explanation for the high poverty rates of widows. Among the widowed couples, wealth in all the categories declined between 1977 and 1979 (Table 16). 19 Similar calculations over all transition years in the RHS show that total median wealth declined by 318 during the years of the husband's death compared with an increase of 28 over the same years among surviving couples. Most of the loss is in Social Security wealth, which is to be expected: according to the Social Security rules the couple's benefit is reduced when the husband dies. For couples of this age and cohort the typical reduction would be about 338 of the couple's benefit. Because the poverty line of a single elderly person is just 218 below the poverty line of an elderly couple, the difference in the changes in Social Security benefits and the poverty line will itself cause some widows to become poor. There is no particular reason to believe that either factor properly reflects returns to scale in consumption: both are arbitrary.

Table 16 shows that pension wealth declines sharply when the husband dies: at the time of the RHS most husbands did not have pensions with survivorship rights (Myers, Burkhauser and Holden, 1986). The Retirement Equity Act of 1984 is meant to encourage the choice of a pension with survivorship rights. Previously the pension beneficiary (typically the husband) could choose a pension with no survivorship rights. Since 1984 the pension will have survivorship rights unless both the husband and the wife request otherwise. Simulations over the RHS population show that changing all pensions to have survivorship rights would have raised substantially the incomes of those widows whose husbands had pensions without survivor's benefits. However, the poverty rate of all widows would have been remained high, about 228 , compared with 268 before the change. The effect on the poverty rate was small for two reasons: first, about 308 of pensions had survivor's benefits already; second, there is 
a strong positive association between economic status and pension eligibility, so that few of the poor widows would have been eligible for pension benefits even with survivorship rights. This general result should carry over to the population. It is hard to see that survivorship rights to pensions will have a large impact on the high poverty rates of widows.

The causes of the high rates of poverty among elderly widows are varied and complex. Some families reach retirement already poor or near poor. Were the husband to survive the family would have a high risk of poverty, but because husbands in poor families tend to die sooner than husbands in wealthy families, often the widow inherits the family's poverty. In addition some sources of income drop when the husband dies and some wealth is reduced. How much poverty is due to the spending of assets as an individual ages is not clear. Crosssection poverty rates have cohort effects: the oldest are from cohorts that had lower lifetime earnings. We need panel data over, say, 20 years to control for cohort effects: we could then observe the life cycle effects.

\subsection{Wealth.}

Although income is practically the only measure of economic status in use, life cycle considerations suggest that, at least for the retired elderly, wealth is a better measure because it measures consumption opportunities. However, the kinds of intergenerational comparisons that are based on income cannot easily be made using wealth because a large fraction of the wealth of workers is future earnings, which are not observed. Even wealth comparisons among the retired elderly of different ages are not straightforward because of variation in life expectancy: for example, who is better off, a 70 year-old with $\$ 100,000$ or an 80 year-old with $\$ 50,000$ ? One could, of course, calculate the annuity each could purchase to translate the comparison into income terms, but the 
consumption path implied by the annuity might not be the desired path. Another method would be to ask whether the 70 year-old he would have more or less than $\$ 50,000$ should he 1 ife to 80 . This involves finding the optimal consumption path. Although there has been some research on consumption paths of the elderly (to be discussed later), the research is not well-enough advanced to make confident comparisons based on the estimated paths. Notwithstanding these problems of comparison, wealth data are a valuable alternative or supplement to income data.

The following table has estimates of average bequeathable wealth of the elderly. 20

$\begin{array}{lccc} & \text { 1984 SIPP } & \begin{array}{c}1983 \text { SCF } \\ \text { without supplement }\end{array} & \begin{array}{c}1983 \text { SCF } \\ \text { with supplement }\end{array} \\ \text { Mean } & 91,000 & 106,000 & 250,000 \\ \text { Median } & 60,000 & \text { n.a. } & 52,000 \\ & & & \\ & & \text { Avery and Elliehausen, 1986; SCF without }\end{array}$

Both the Survey of Program Participation (SIPP) and the Survey of Consumer Finances ( $S C F$ ) without supplement are self-weighting samples. 21 The estimates of mean wealth differ somewhat but they are probably not significantly different. (Given the typical dispersion of wealth, the standard errors are bound to be very large.) The SCF with supplement differs from the SCF without supplement by the addition of 438 high income households. 22 Even though both of the SCF estimates of mean wealth are weighted by the sampling weights, so that, in principle, the means should be the same, the estimates are widely different. This happens because wealth is so highly concentrated. (The Gini coefficient in 
the wealth of the elderly is 0.78 from the SCF with supplement (McDermed, Clark and Allen, 1987), whereas the Gini coefficient of income is about 0.35 . The fraction of wealth in the top 1 of the wealth distribution is about 35\%.) The high concentration of wealth, makes it difficult to find wealth measures that represent the situation of most of the elderly. An alternative to the mean is, of course, the median. But it has drawbacks for studying the sources of wealth, which has been an important research topic: the medians of the wealth components cannot be aggregated and some categories will have medians of zero. For these reasons and for comparability with the RHS and other data sets (which are self-weighting), I analyze mean wealth from the SCF without supplement and from the SIPP.

Mean wealth of the elderly was about $\$ 100,000$ in these data sets. This does not include a few asset categories such as consumer durables, but much more important from the point of view of describing available resources it does not include any claim on Social Security, pensions or Medicare/Medicaid. At a real interest rate of $3 z$ the assets add just $\$ 3,000$ per year to income from other sources. This is about $18 \%$ of the average household income of the elderly in $1983(\$ 16,386)$. Should an elderly person consume part of the wealth as he ages, the wealth could make a much higher contribution to consumption. Suppose, for example, a 70 year-old woman chose a flat consumption over 15 years, which is about her life expectancy. At a real interest rate of 38 , she could consume $\$ 8,300$ per year (1983\$) from the wealth. This is about 518 of average income in 1983. Of course, a flat consumption path is probably not optimal (she might live to 86 ), but the example implies that, on average, wealth accumulation for retirement is adequate, provided the wealth is consumed.

To form a complete picture of the resources of the elderly we need more inclusive wealth measures than are available from either the SCF or the SIPP. Table 18 has fully inclusive average net wealth from the 1975 and 1979 RHS. The 
ages of most of the heads of households were $64-69$ in 1975 and $68-73$ in 1979, so the table shows wealth near the beginning of retirement. In fact, future earnings accounted for only 68 of wealth in 1975 and 38 in 1979, so, practically speaking, the sample had retired by 1979. Financial wealth includes stocks and bonds, savings accounts and so forth. Flows (all but the first three entries) are converted to stocks through actuarial discounting, either real or nominal depending on the flow. SSI is Supplemental Security Income, a means-tested old age welfare program. Transfers includes transfers from relatives and children. Medicare and Medicaid is the expected present value of the per household transfer through the Medicare and Medicaid program evaluated at cost, the market value discussed earlier. 23

The average wealth levels are reasonably high and consistent with independent measures of income and wealth. 24 I imagine, however, that most people would be surprised at how little saving is in the conventional form of financial, business and property wealth: about 228 in 1975 and 238 in 1979. Adding in housing equity to find the fraction of saving that takes place at the household level brings these figures to 368 and 418 . Pensions and Social Security, which are savings done by firms and society on behalf of the household, accounted for 468 in 1975. Both in levels and as percentages of total wealth, the sum of pensions and Social Security fell between 1975 and 1979 because of higher mortality discounting as the RHS sample aged, and, in the case of pensions, because inflation reduced the real value. Undoubtedly, for the same reasons I discussed earlier in connection with the valuation of the income flow from Medicare and Medicaid, the most controversial entry is the wealth value of Medicare and Medicaid. 25 It accounted for 108 of wealth in 1975 and 128 in 1979.26 Its value rose between 1975 and 1979 despite the aging of the RHS population (the actuarial discounting is higher at greater ages) because the growth in Medicare and Medicaid transfers was much higher than the inflation 
rate.

The level of wealth in the lowest wealth decile is low indeed, and consists almost entirely of wealth from public programs. Any underreporting is not likely to be substantial because most underreporting is associated with financial assets; but even allowing for some, it is clear that many elderly reach retirement with very little. Research has not discovered why this happens. 
1. An additional reason for this difference is that women tend to marry older men.

2. A households is classified as elderly if the "householder" is elderly; earnings can come from a nonelderly spouse.

3. In much of this section $I$ use averages or other summary measures. The elderly are a very diverse population, however, so the averages will mask the 4. Although the consumption bundles of the elderly and the nonelderly are somewhat different, a Laspayres index based on the consumption bundle of the elderly has varied little from the CPI over either short or long time periods (Boskin and Hurd, 1985; Bridges and Packard, 1982). Therefore, I use the CPI to convert nominal dollars to real dollars unless the original research used some other index.

5. The poverty scaling is rather arbitrarily based on food consumption in 1955 (Palmer, Smeeding and Jencks, 1988).

6. In 1984 average hourly real nonagricultural earnings were almost exactly the same as in 1967. Table B-44, 1988 Economic Report of the President.

7. The table does not show the experience of any cohort; it measures changes in the means of the deciles of each age interval.

8. There was, of course, some change in composition due to mortality between 1979 and 1984, which probably tended to increase average income. This issue will be discussed later in connection with age-related wealth changes.

9. The validation study used outside information from Social Security and IRS records to check the accuracy of income items in the 1973 CPS.

10. In addition to the studies already discussed, see Boskin and Shoven (1987); Danziger et. al. (1984a, 1984b); Hurd and Shoven (1982, 1984); Ross, Danziger and Smolensky (1987).

11. Income is observed cash income from the CPS adjusted for household size 
according to the poverty scale.

12. In 1987 the poverty rate of the elderly was 12.28 and of the population was 13.58. This more recent data does not have the age detail of Table 14 .

13. The entries under money income vary from the official poverty levels (and from the levels in Table 14) because of difference is weighting.

14. The method aims to find the expenditures the recipient family would have made, given its characteristics and income, if it had purchased the nonmoney transfers in markets. The ratio of the estimated expenditures to the market value of the transfers in the benefit weight. The benefit weight for Medicare and Medicaid transfers is 0.42 (Smeeding, 1982).

15. For example, it seems unlikely that if a two-person elderly household at the poverty line $(\$ 4,400)$ were given an additional $\$ 1,344$ and the opportunity to buy into the Medicare and Medicaid program, it would choose to spend the full $\$ 1,344$ in such a way.

16. Table 16 is an example of many similar results obtained when the classification is by marital transition in other years.

17. Similar results have been obtained by Jianakoplos et al (1989) in the National Longitudinal Survey of older men.

18. Age will cause differences in the wealth measures of Social Security and pensions because the discounting that converts the future flows to stocks rises with age. But the wealth differences are too large to be caused by age differences: the husbands in the widowed couples were about 0.35 year older than the husbands in the surviving couples.

19. Earnings are not shown in the table: because the husbands were $66-71$ year old in 1977 , median earnings were zero.

20. Family unit wealth in the SCF; household wealth in the SIPP.

21. Wealth includes financial assets, real estate, and housing equity, all net of debts. It excludes pension and Social Security wealth, the cash value of 
life insurance and household durables. The SCF also excludes the value of automobiles and equity in small businesses and farms. The sample sizes are 3824 (SCF) and 18,700 (SIPP) all ages included.

22. Although weights are given for the high income households, it is by no means clear that weighted averages are accurate: only 98 of the high income families that were asked to participate in the survey responded that they would participate. This raises obvious questions about the representativeness of the sample.

23. This is the method used by smeeding (1989), and by Clark, et. al. (1984). 24. For example, Smeeding (1989) calculates full income of the elderly to be $\$ 13,423$; if the wealth in 1979 were annuitized at a 78 interest rate and 48 mortality rate, it would yield $\$ 16,137$. Given that this applies to $68-73$ year olds who are more wealthy than older cohorts, the figures seem quite consistent. Radner (1989) reports mean financial and housing wealth of $65-74$ year-olds from the SIPP to be $\$ 99,800$, which is $\$ 69,700$ in 1979 dollars. The comparable wealth figure in the 1979 RHS, when most heads of households were 68-73, is $\$ 71,100$. However, both the SIPP and the RHS wealth figures are substantially below the SCF (without supplement) wealth figures: for $65-74$ year-olds they are $\$ 91,300$ in 1979 dollars.

25. The market valuation for most elderly may be fairly accurate: many elderly purchase additional medical insurance beyond Medicare and Medicaid. This indicates that, from Medicare and Medicaid alone, they are not at a corner solution in their demand for medical coverage, and that, apart from wealth effects, market valuation is appropriate. This argument would not hold for the poor elderly many of whom do not purchase additional medical coverage (U.S.

Senate Special Committee on Aging).

26. These fractions are very close to the fraction of income from Medicare and Medicaid (108) in Smeeding (1989). 
Table 1

Fraction of Population of Different Ages:

Actual, 1900-1980 and Predicted 1990-2050 (Middle Series)*

\begin{tabular}{|c|c|c|c|c|c|c|c|c|}
\hline & $\begin{array}{r}\text { aged } \\
55-59 \\
\end{array}$ & $\begin{array}{r}\text { aged } \\
60-64 \\
\end{array}$ & $\begin{array}{r}\text { aged } \\
65-69 \\
\end{array}$ & $\begin{array}{r}\text { aged } \\
70-74 \\
\end{array}$ & $\begin{array}{c}\text { aged } \\
75+ \\
\end{array}$ & $\begin{array}{r}\text { aged } \\
75-79 \\
\end{array}$ & $\begin{array}{r}\text { aged } \\
80-84 \\
\end{array}$ & $\begin{array}{c}\text { aged } \\
85+ \\
\end{array}$ \\
\hline 1900 & 3 & 2 & 2 & 1 & 1 & & & \\
\hline 1910 & 3 & 2 & 2 & 1 & 1 & & & \\
\hline 1920 & 3 & 3 & 2 & 1 & 1 & & & \\
\hline 1930 & 4 & 3 & 2 & 2 & 2 & & & \\
\hline 1940 & 4 & 4 & 3 & 2 & 2 & & & \\
\hline 1950 & 5 & 4 & 3 & 2 & 3 & & & \\
\hline 1960 & 5 & 4 & 3 & 3 & 3 & & & \\
\hline 1970 & 5 & 4 & 3 & 3 & 4 & & & \\
\hline 1980 & 5 & 4 & 4 & 3 & 4 & 2 & 1 & 1 \\
\hline
\end{tabular}

\begin{tabular}{rrrrrrrrr} 
aged aged & aged \\
$55-59$ & $60-64$ & $65-69$ & $70-74$ & $75-79$ & $80-84$ & $85-89$ & $90-94$ & $95+$ \\
\hline
\end{tabular}

1990

2000

2010

2020

2030

2040

2050

$\begin{array}{lll}4 & 4 & 4 \\ 5 & 4 & 3 \\ 7 & 6 & 4 \\ 7 & 7 & 6 \\ 6 & 6 & 6 \\ 6 & 5 & 5 \\ 6 & 6 & 5\end{array}$

$\begin{array}{ll}3 & 3 \\ 3 & 3 \\ 3 & 2 \\ 4 & 3 \\ 5 & 4 \\ 5 & 4 \\ 4 & 4\end{array}$

2
2
2
2
3
4
3

$\begin{array}{lll}1 & 0 & 0 \\ 1 & 1 & 0 \\ 1 & 1 & 0 \\ 1 & 1 & 0 \\ 2 & 1 & 0 \\ 2 & 1 & 1 \\ 3 & 2 & 1\end{array}$

Source: U.S. Bureau of the Census, Current Population Reports Series P-25, No. 952. Projections of the Population of the U.S. by Age. Sex. and Race 1983-2080. May 1984: table 6 .

* The middle series (series 14) is based on intermediate assumptions about fertility, mortality and immigration. 
Actual and Predicted Life Expectancy at Age 65 Male Female

1900

1910

1920

1930

1940

1950

1960

1970

1980

1990

2000

2010

2020

2030

2040

2050

2060
11.3

11.4

11.8

11.4

11.9

12.8

12.9

13.1

14.1

15.0

15.7

16.1

16.5

16.8

17.1

17.4

17.8
12.0

12.1

12.3

12.9

13.4

15.1

15.9

17.1

18.3

19.5

20.5

21.2

21.7

22.1

22.6

23.1

23.6

Source: Committee on Ways \& Means, 1987. 
Table 3

Distribution of Living Arrangements of the Elderly, Men and Women (Percent)

\begin{tabular}{lll} 
& \multicolumn{2}{c}{ Men } \\
\cline { 2 - 3 } With $65+$ & Non- \\
Spouse Blone Relatives relatives
\end{tabular}

$\begin{array}{lll} & \text { Women } & \text { Non- } \\ \text { With } & & \\ \text { Spouse Alone Relatives relatives Total }\end{array}$

$\begin{array}{llllllllll}1960 & 69 & 12 & 14 & 4 & 100 & 36 & 24 & 34 & 4 \\ 1970 & 71 & 15 & 10 & 5 & 100 & 36 & 34 & 26 & 4 \\ 1980 & 75 & 14 & 8 & 3 & 100 & 37 & 40 & 20 & 100 \\ 1985 & 75 & 15 & 7 & 3 & 100 & 38 & 41 & 18 & 2\end{array}$

age $65-74$

$\begin{array}{llllllllll}1960 & 75 & 11 & 10 & 4 & 100 & 44 & 23 & 28 & 5 \\ 1970 & 76 & 12 \star & 8 & 4 \star & 100 & 45 & 31 \star & 20 & 100 \\ 1980 & 80 & 11 & 6 & 3 & 100 & 48 & 35 & 16 & 100 \\ 1985 & 79 & 12 & 6 & 3 & 100 & 49 & 35 & 14 & 1\end{array}$

Age $75+$

$\begin{array}{lllllllllll}1960 & 57 & 15 & 22 & 6 & 100 & 20 & 26 & 46 & 7 & 36 \\ 1970 & 60 & 20 \star & 16 & 4 \star & 100 & 21 & 37 \star & 36 & 100 \\ 1980 & 66 & 21 & 11 & 2 & 100 & 21 & 48 & 27 & 4 \\ 1985 & 67 & 20 & 10 & 3 & 100 & 23 & 50 & 25 & 100\end{array}$

Sources

1985 Data: U.S. Bureau of the Census, Current Population Reports Series P-20,

No. 410, Martial Status and Living Arrangements: March 1985, Table A-12.

1980 Data: U.S. Bureau of the Census, 1980 Census of Population, PC80-2-4B,

Living Arrangements of Children and Adults, Table 4 and Current Population

Reports, Series P-20, No. 3651, Marital Status and Living Arrangements:

March 1980, Table 6.

1970 Data: U.S. Bureau of the Census, 1970 Census of Population, PC(2)-4B,

Persons by Family Characteristics, Tables 2 and 11.

1960 Data: U.S. Bureau of the Census, 1960 Census of Population, PC(2)-4B.

Persons by Family Characteristics. Tables 2 and 15.

* Interpolations. Age detail not available.

Note: Noninstitutional population 
Table 4

Mean Household Income of the Elderly and of the Population, 1983 Dollars

Year

Mean 65t

Mean A11

$\underline{\text { Ratio }}$

1970

13,901

25,660

16,188

26,580

1975

15,268

25,467

17,411

26,919

18,006

27,949

.60

.65

1986

Source: Money Income of Households, Families and Persons, Current Population Reports. Series P-60, various years. 
Table 5

Distribution of Sources of Income (Percent)

$\begin{array}{lcccr} & 1967 & 1976 & 1984 & 1986 \\ \text { Earnings } & 29 & 23 & 16 & 17 \\ \text { Social Security } & 34 & 39 & 38 & 38 \\ \begin{array}{l}\text { Pensions \& Other } \\ \text { Retirement }\end{array} & 15 & 16 & 15 & 16 \\ \text { Assets } & 15 & 18 & 28 & 26 \\ \text { Public Assistance } & 4 & 2 & 1 & 1 \\ \text { Other } & 3 & 2 & 2 & 2 \\ \text { Total } & 100 & 100 & 100 & 100\end{array}$

Source: "Retirement Income for an Aging Population" and "Income of the Population 55 \& Over, 1986", Current Population Reports. 
Table 6

Percentage Distribution of Elderly Households by Importance of Income Source

$\underline{1971} \quad \underline{1980} \quad \underline{1986}$

A. Earnings

Total Percent

100

100

100

0

$1-49$

$50-100$

90-100

$\begin{array}{rrr}69 & 78 & 81 \\ 16 & 12 & 11 \\ 15 & 10 & 8 \\ 5 & 2 & 2\end{array}$

B. Social Security

Total Percent

100

100

100

0

$1-49$

13

38

49

17

9

8

50-100

90-100

32

35

57

23

24

C. Private Pensions \& Annuities

Total Percent

100

100

100

0

$1-19$

20-49

50-100

83

$79 \quad 74$

$\begin{array}{rrr}6 & 10 & 13 \\ 8 & 9 & 11\end{array}$

3

11
2

D. Government Pensions

Total Percent

100

100

100

0

1-49

$50-100$

94

89

87

78

3

5

E. Income from Assets

Total Percent

100

100

100

0

51

27

1-19

20-49

$50-100$

15

7

40

30

$\begin{array}{rr}17 & 18 \\ 9 & 12\end{array}$

Sources: Income of the population aged 60 and older, Social Security Administration, various years. 
Table 7

Labor Force Participation Rates (Percent)

$\underline{\text { Men }}$

Women

Year $\underline{55-59} \quad \underline{60-64} \underline{65-69} \quad 70-74 \quad 75+\quad \underline{55-59} \quad \underline{60-64} \quad \underline{65-69} \quad 70-74 \quad 75+$

$\begin{array}{llllllllllll}1957 & 91.4 & 82.9 & 52.6 & * & * & 38.2 & 30.3 & 17.5 & * & & \end{array}$

$\begin{array}{lllllllllll}1965 & 90.2 & 78.0 & 43.0 & 24.8 & 14.1 & 47.1 & 34.0 & 17.4 & 9.1 & 3.7\end{array}$

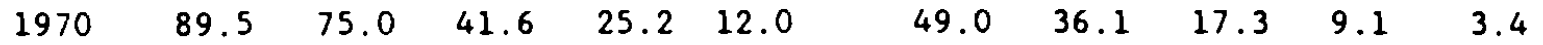

$\begin{array}{lllllllllll}1975 & 89.4 & 65.5 & 31.7 & 21.1 & 10.1 & 47.9 & 33.2 & 14.5 & 7.6 & 3.0\end{array}$

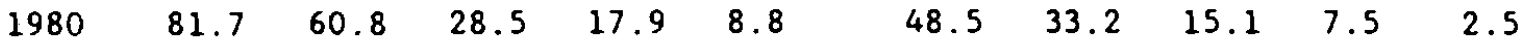

$\begin{array}{lllllllllll}1985 & 79.6 & 55.6 & 24.5 & 14.9 & 7.0 & 50.3 & 33.4 & 13.5 & 7.6 & 2.2\end{array}$

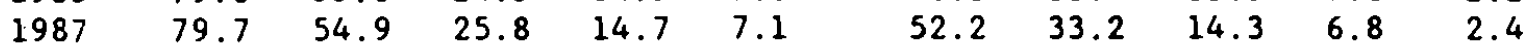

Source: Labor Force Statistics Derived from the CPS, 1948-1987. U.S. Department of Labor, Bureau of Labor Statistics, \#2307, August, 1988.

* Not available 
Table 8

Growth in Average Real Family Unit Income

Annual Income Growth (8)

$\underline{1967-1979} \quad \underline{1979-1984}$

Income in

1984*

A. No Size Adjustment

Under 65

$65+$

B. Size Adjustment

Under 65
$65+$
$65-69$
$70-74$
$75-79$
$80-84$
$85+$

Source: Radner (1987)

* Measured in 1982 dollars.
1.0
$-0.4$
27,464
1.5
3.4
18,279

$\begin{array}{ll}1.7 & 0.5 \\ 2.2 & 3.7 \\ 1.8 & 3.8 \\ 2.1 & 4.2 \\ 3.0 & 3.1 \\ 2.9 & 3.3 \\ 2.7 & 5.5\end{array}$

16,293

14,160

16,496

14,401

12,617

11,469

11,825 
Table 9

Annual Percentage Change of Average Real Family Unit Income Adjusted for Size

\section{Age of Head}

20-24

$25-29$

$30-34$

$35-39$

$40-44$

$45-49$

$50-54$

55-59

60-64

65-69

70-74

75-79

80-84

$85+$

\section{$\frac{\text { 2nd decile }}{\underline{1967-79} \quad \text { 1979-84 }}$}

0.9

0.3

1.8

1.5

1.7

1.0

1.2

2.2

2.5

3.2

3.2

4.0

4.2

5.5

1.1

3.6

Age $65+$
$-7.4$

$-4.4$

$-3.3$

$-1.6$

$-2.2$

$-1.3$

$-2.2$

$-2.6$

0.5

3.7

2.0

2.4

1.9

1.2

$-2.8$

2.3

$\frac{9 \text { th decile }}{\underline{1967-79} \quad \underline{1979-84}}$

1.3

1.7

2.6

2.7

2.3

1.9

1.9

2.4

1.9

1.5

2.0

2.8

2.1

2.5

1.9

1.1

1.8

3.7

Source: Radner (1987). 
Table 10

Income of the Elderly Relative to the Nonelderly, 1979

\begin{tabular}{clll}
\multicolumn{4}{c}{ Income } \\
\hline & Poverty & Budget \\
Line & Share & Per \\
Household & Index & Index & capita \\
\hline
\end{tabular}

\begin{tabular}{|c|c|c|c|}
\hline & Poverty & Budget & \\
\hline Household & $\begin{array}{l}\text { Line } \\
\text { Index }\end{array}$ & $\begin{array}{l}\text { Share } \\
\text { Index }\end{array}$ & $\begin{array}{c}\text { Per } \\
\text { capita }\end{array}$ \\
\hline
\end{tabular}

A. Conventional

0.52

0.64

0.84

0.90

0.66

0.82

1.07

1.16 income

B. Conventional income plus Employment 0.65 0.80 1.04 1.14 0.79

0.99

1. 28

1.40 enefits, and Income-in-kind Less taxes

Note: Entries are the ratios of household incomes of the elderly to the nonelderly.

Source: Smeeding (1989), and author's calculations. 
Table 11

Distribution of Income

\author{
Year, Data \\ and Income Measure
}

1973 Consumer

Expenditure Survey ${ }^{1}$

$1979 \mathrm{CPS}^{2}$

1979 CPS; Adjusted ${ }^{3}$

1967 CPS; Family

Size Adjustment ${ }^{4}$

1979 CPS; Family

Size Adjustment ${ }^{4}$

1984 CPS; Family

Size Adjustment"
Gini Coefficients

Age $<65$ Age $\geq 65$

0.36

0.44

0.43

0.35

0.31

0.35

0.42

0.40

0.36

0.40

0.42

44.2

40.4

49.8

40.6

49.5

37.2

42.8

0.36

41.6

51.6

41.3

47.1

48.1

1 Danziger et.al. 1984a. Household income.

2 Smeeding, 1989. Household income.

3 Smeeding, 1989. Household income adjusted for nonmoney income, taxes and employment-related income as in Table 10, B, "Income", "Household".

" Radner, 1987, Family unit income. Size adjustment based on poverty scale. 
Table 12

\begin{tabular}{|c|c|c|c|c|c|c|}
\hline Income Quintile & Year & $\begin{array}{l}\text { Total } \\
\text { Income }\end{array}$ & Earnings & $\begin{array}{l}\text { Social } \\
\text { Security } \\
\text { Benefits }\end{array}$ & Property & other \\
\hline Lowest & $\begin{array}{l}1967 \\
1979 \\
1984\end{array}$ & $\begin{array}{l}2,116 \\
3,484 \\
3,986\end{array}$ & $\begin{array}{l}54 \\
65 \\
73\end{array}$ & $\begin{array}{l}1,589 \\
2,694 \\
3,102\end{array}$ & $\begin{array}{l}107 \\
142 \\
168\end{array}$ & $\begin{array}{l}366 \\
583 \\
643\end{array}$ \\
\hline Highest & $\begin{array}{l}1967 \\
1979 \\
1984\end{array}$ & $\begin{array}{l}23,572 \\
27,798 \\
34,061\end{array}$ & $\begin{array}{r}14,352 \\
10,379 \\
9,450\end{array}$ & $\begin{array}{l}2,344 \\
4,811 \\
5,901\end{array}$ & $\begin{array}{r}4,801 \\
8,047 \\
13,289\end{array}$ & $\begin{array}{l}2,076 \\
4,561 \\
5,421\end{array}$ \\
\hline
\end{tabular}

Source: Radner (1987) Table 14.

Table 13

Social Security Income of Family Units (1982 \$) Adjusted for Size

\begin{tabular}{lcccccc} 
& \multicolumn{2}{c}{ All Deciles } & & \multicolumn{2}{c}{ Fifth Decile } \\
Age and Year & & $\begin{array}{c}\text { Social Security } \\
\text { Income }\end{array}$ & $\begin{array}{c}\text { Percent } \\
\text { of Total }\end{array}$ & & $\begin{array}{c}\text { Social Security } \\
\text { Income }\end{array}$ & $\begin{array}{c}\text { Percent } \\
\text { of Total }\end{array}$ \\
$70-74 ; 1967$ & 2,850 & 31 & & 3,320 & 55 \\
$75-79 ; 1972$ & 3,880 & 37 & & 4,570 & 67 \\
$80-84 ; 1977$ & 4,330 & 38 & & 4,960 & 71 \\
$85-89 ; 1982$ & 4,560 & 37 & & 5,270 & 70
\end{tabular}

Source: Radner (1987). 
Poverty Rates of Family Units (Percent) Based on Family Unit Money Income

\begin{tabular}{|c|c|c|c|}
\hline Age & 1967 & 1979 & 1984 \\
\hline Under 65 & 11.8 & 11.1 & 14.5 \\
\hline $65+$ & 28.1 & 15.1 & 12.4 \\
\hline $65-69$ & 21.9 & 12.2 & 9.4 \\
\hline $70-74$ & 25.8 & 13.4 & 11.5 \\
\hline $75-79$ & 33.8 & 17.9 & 13.7 \\
\hline $80-84$ & 38.2 & 19.4 & 17.7 \\
\hline $85+$ & 38.9 & 22.7 & 18.5 \\
\hline
\end{tabular}

Source: Radner (1987) p. 19.

Table 15

Poverty Rates of Widows (Percent)

\begin{tabular}{|c|c|c|c|c|c|}
\hline \multirow[b]{2}{*}{ Year } & \multirow[b]{2}{*}{$\underline{60-61}$} & \multirow[b]{2}{*}{$\underline{62-64}$} & \multicolumn{3}{|c|}{65 and over } \\
\hline & & & Total & $\underline{65-71}$ & $72 \pm$ \\
\hline 1971 & - & - & 35.1 & - & - \\
\hline 1976 & 22.8 & 22.9 & 23.3 & 21.7 & 24.0 \\
\hline 1981 & 26.2 & 27.2 & 25.4 & 23.9 & 26.1 \\
\hline 1984 & 27.6 & 25.5 & 20.1 & 18.3 & 20.9 \\
\hline 1986 & 21.0 & 20.3 & 21.0 & 19.8 & 21.4 \\
\hline
\end{tabular}

Sources: Current Population Reports, Series P-60, various years. 
Table 16

Median Wealth by Change in Marital Status Between 1977 and 1979 (Thousands of 1979 \$)

\begin{tabular}{|c|c|c|c|c|c|c|c|c|}
\hline \multirow[b]{2}{*}{$\begin{array}{l}\text { Marital } \\
\text { Transition } \\
1977-1979 \text { : }\end{array}$} & \multicolumn{2}{|c|}{ Bequethable Wealth } & \multicolumn{2}{|c|}{$\begin{array}{l}\text { Beque thable } \\
\text { Plus Housing }\end{array}$} & \multicolumn{2}{|c|}{$\begin{array}{l}\text { Social } \\
\text { Security }\end{array}$} & \multicolumn{2}{|c|}{$\begin{array}{l}\text { Pensions and } \\
\text { Annuities }\end{array}$} \\
\hline & $\begin{array}{c}\text { Couple } \\
\text { to } \\
\text { Couple }\end{array}$ & $\begin{array}{c}\text { Couple } \\
\text { to } \\
\text { Widow } \\
\end{array}$ & $\begin{array}{l}\text { Couple } \\
\text { to } \\
\text { Couple }\end{array}$ & $\begin{array}{c}\text { Couple } \\
\text { to } \\
\text { Widow }\end{array}$ & $\begin{array}{c}\text { Couple } \\
\text { to } \\
\text { Couple }\end{array}$ & $\begin{array}{c}\text { Couple } \\
\text { to } \\
\text { Widow }\end{array}$ & $\begin{array}{c}\text { Couple } \\
\text { to } \\
\text { Couple }\end{array}$ & $\begin{array}{c}\text { Couple } \\
\text { to } \\
\text { Widow }\end{array}$ \\
\hline 1969 & 11.9 & 10.2 & 38.7 & 31.8 & 49.3 & 48.4 & 26.0 & 21.3 \\
\hline 1971 & 13.8 & 11.5 & 41.7 & 34.6 & 64.0 & 62.9 & 39.3 & 31.6 \\
\hline 1973 & 13.0 & 10.4 & 43.3 & 36.8 & 73.7 & 70.1 & 27.0 & 23.7 \\
\hline 1975 & 15.9 & 12.4 & 47.8 & 41.7 & 69.4 & 64.2 & 20.4 & 19.3 \\
\hline $1977 \star$ & 15.6 & 11.5 & 48.8 & 47.2 & 67.8 & 63.2 & 23.1 & 19.4 \\
\hline 1979* & 16.0 & 9.8 & 51.2 & 45.0 & 61.0 & 38.6 & 16.2 & 7.0 \\
\hline
\end{tabular}

Table 17

Poverty Rates (Percent)

\begin{tabular}{lcccc} 
& \multicolumn{2}{c}{ Entire Sample } & \multicolumn{2}{c}{ Not Poor in 1975} \\
\cline { 2 - 5 } Year & $\begin{array}{c}\text { Couple } \\
\text { to couple }\end{array}$ & $\begin{array}{c}\text { Couple } \\
\text { to widow }\end{array}$ & $\begin{array}{c}\text { Couple } \\
\text { to couple }\end{array}$ & $\begin{array}{c}\text { Couple } \\
\text { to widow }\end{array}$ \\
\hline & & & & \\
1969 & 5 & 8 & 3 & 5 \\
1971 & 7 & 11 & 4 & 7 \\
1973 & 8 & 8 & 4 & 4 \\
$1975 *$ & 8 & 9 & 0 & 0 \\
$1977 *$ & 7 & 42 & 4 & 37 \\
1979 & 11 & 40 & 11 & 35
\end{tabular}

* Husband in "couple to widow" columns died between these years

Source: Unpublished calculations of Hurd and Wise from the RHS 
Table 18

Average Household Wealth and the Distribution of Wealth by Source, 1975 and 1979 RHS Sample

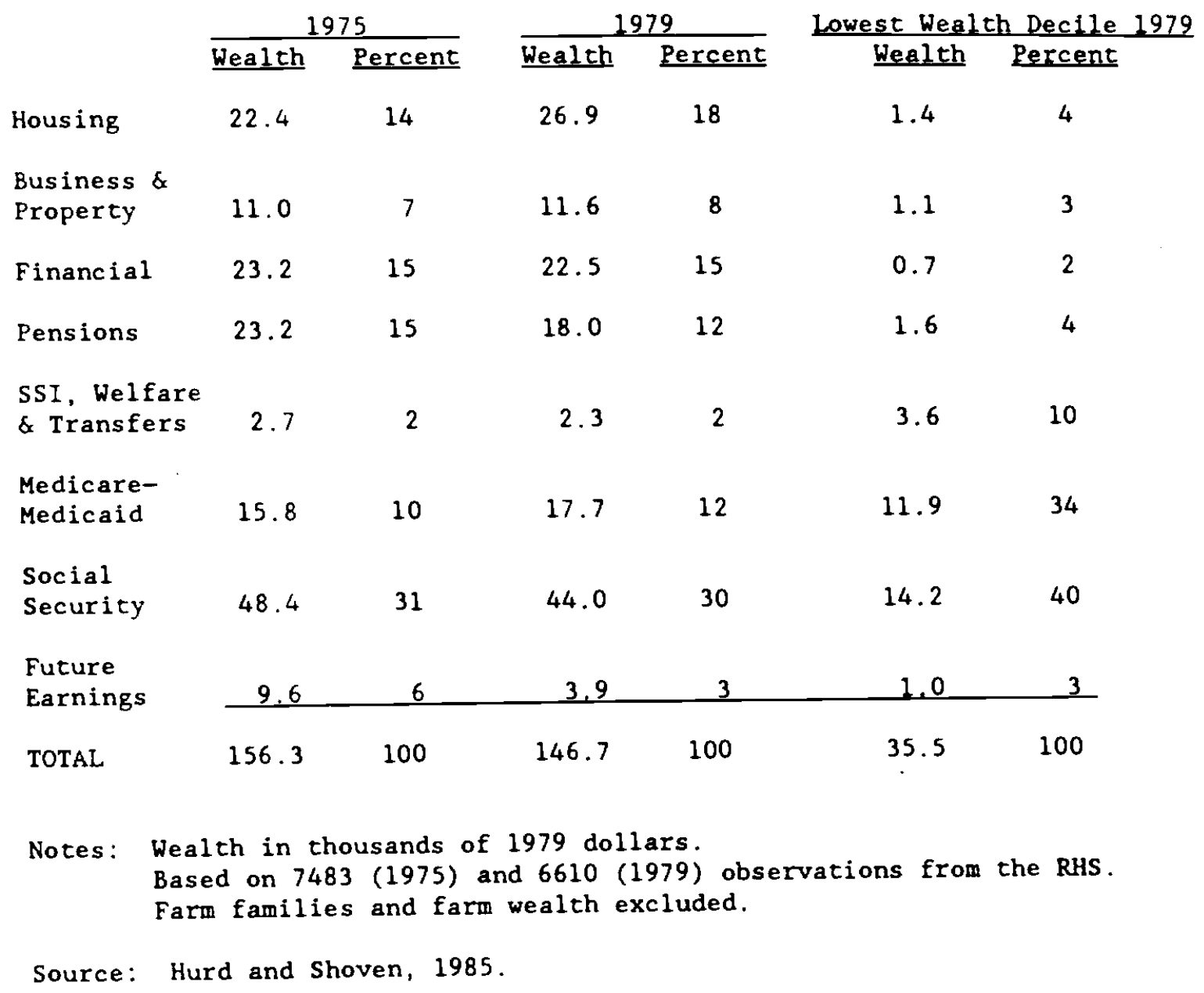




\section{References}

Abel, Andrew B. "Operative Gift and Bequest Motives," American Economic Review. December 1987, Vol.77, No.5, pp.1037-1047.

Anderson, Kathryn $H$. and Richard V. Burkhauser. "The Effect of Actual Mortality Experience Within a Retirement Decision Model," April 1983.

Anderson, Kathryn H., Richard V. Burkhauser and J.S. Butler. "Work after Retirement: A Hazard Model of Labor market Reentry," IRP Discussion Papers. December 1984, WP \#768-84, 1984.

Anderson, Kathryn H., Richard V. Burkhauser and Joseph F. Quinn. "Do Retirement Dreams Come True? The Effect of Unexpected Events on Retirement Age," IRP Discussion Papers, DP \#750-84.

Andrews, Emily, The Changing Profiles of Pensions in America, Washington: Employee Benefit Research Institute, 1985

Andrews, Emily, and Deborah Chollet, "Future Sources of Retirement Income: Whither the Baby Boom, "in Social Security and Private Pensions, Ed: Susan M. Wachter, Lexington, MA: D.C. Health, and Co, 1988, pp 71-95.

Auerbach, Alan J. and Laurence J. Kotlikoff. "Life Insurance of the Elderly: Adequacy and Determinants," pp. 229-267.

Avery, Robert, and Gregory Elliehausen, "Financial Characteristics of High Income Families," Federal Reserve Bulletin, 1986, March, pp. 163-277.

Avery, Robert, Gregory Elliehausen, Glenn Canner and Thomas Gustafson, "Survey of Consumer Finances, 1983: A Second Report, " Federal Reserve Bulletin, 1984, (December), pp. $857-868$.

Berkovec, James and Steven Stern. "Job Exit Behavior of Older Men," Discussion Paper No.169, Department of Economics, University of Virginia, 1988.

Bernheim, Douglas B. "Life Cycle Annuity Valuation," NBER Working Paper 1511, December, 1984.

Bernheim, Douglas B. "Dissaving after Retirement: Testing the Pure life Cycle Hypothesis," in Issues in pension economics. Eds.: Zvi Bodie, John B. Shoven and David A. Wise. Chicago, Univ.: National Bureau of Economics Research, Inc. 1987.

Bernheim, Douglas B, Andrei Shleifer and Lawrence H. Summers, "The Strategic Bequest Motive," Journal of Political Economy, 1985, 93 (6) pp 1045-1076.

Blinder, Alan S., Roger H. Gordon and David A. Wise. "Reconsidering the Work Disincentive Effects of Social Security," National Tax Journal, 1980, 33 (December) $431-442$.

Blinder, Alan S., Roger H. Gordon and David A. Wise. "Social Security, Bequests and the Life Cycle Theory of Saving: Cross-Sectional Tests," in Income Distribution and Economic Inequality, Ed: Zvi Grilliches, New York: Halstead Press, 1983. 
Bodie, Zvi, Alan Marcus and Robert Merton, "Defined Benefit versus Defined Contribution Pension Plans: What Are the Real Trade-offs," in Ed: Z. Bodie, J. Shoven and D. Wise, Pensions in the U.S. Economy. Chicago: The University of Chicago Press, 1988.

Boskin, Michael J. and Michael D. Hurd. "Indexing Social Security Benefits: A Separate Price Index for the Elderly?" Public EInance Quarterly. October 1985, Vol.13, No.4, pp.436-449.

Boskin, Michael J, Laurence J. Kotlikoff, Douglas J. Puffert and John B. Shoven. "Social Security: A Financial Appraisal Across and Within Generations," National Tax Journal. March 1987, Vol.XL, No.1, pp. 19-34.

Boskin, Michael J., and Lawrence J. Lau, "An Analysis of Postwar U.S. Consumption and Saving," Stanford University, mimeo, 1988.

Boskin, Michael J. and John B. Shoven. "Concepts and Measures of Earnings Replacement During Retirement," in Issues in pension economics. Eds.: Zvi Bodie, John B. Shoven, and David A. Wise. Chicago: The University of Chicaco Press, 1987 .

Bridges, Benjamin and Michael Packard, "Price and Income Changes for the Elderly," Social Security Bulletin, 1981, 44 (1), pp. 3-15.

Burkhauser, Richard V. "The Pension Acceptance Decision of Older Workers," The Journal of Human Resources, XIV(1), 1979, pp. 63-75.

Burkhauser, Richard, Karen C. Holden and Daniel Feaster. "Incidence, Timing, and Events Associated with Poverty: A Dynamic View of Poverty in Retirement," Journal of Gerontology, 43, no. 2 (March), 1988, pp S46-S52.

Burkhauser, Richard V., Karen C. Holden and Daniel A. Myers. "Marital Disruption and Poverty: the Role of Survey Procedures in Artificially Creating Poverty," Demography, November 1986, Vol.23, No.4, pp.621-631.

Burkhauser, Richard V. and Jennifer L. Warlick. "Disentangling the Annuity from the Reddistributive Aspects of Social Security in the United States, "Review of Income and Wealth, Series 27, December 1981, 401-421.

Burtless, Gary, and Jerry Hausman, "The Effect of Taxation on Labor Supply: Evaluating the Gary Income Maintenance Experiment," $J$ of Political Economy, 1978,86 (December), pp 1103-1130.

Burtless, Gary and Moffitt, Robert A. "The Effect of Social Security Benefits o1 the Labor Supply of the Aged," in Retirement and economic behavior. Eds.: Henry $\mathrm{J}$. Aaron and Gary Burtless. Washington, D.C.: The Brookings Institution, 1984.

Burtless, Gary and Robert A. Moffitt. "The Joint Choice of Retirement Age and Postretirement Hours of Work," Journal of Labor Economics. 1985, Vol. 3 , No.2, pp. 209-236.

Burtless, Gary and Robert A. Moffitt. "Social Security, Earnings Tests, and Age at Retirement," Public Finance, January 1986, Vol.14, No.1, pp.3-27.

Clark, Robert L., stephen F. Gohmann and Ann A. McDermed. "Declining Use of 
Defined Benefit Pension Plans: Is Federal Regulation the Reason?" April 1988 , Department of Economics, North Carolina State University, Working Paper No. 119.

Clark, Robert L., Juanita Kreps and Joseph Spengler, "Economics of Aging," Journal of Economic Literature, 1978, $919-962$.

Clark, Robert L., George Maddox, Ronald Schrimper, and Daniel Sumner. Inflation and the Economic Well-being of the Elderly. Baltimore: Johns Hopkins University Press, 1984.

Crawford, Vincent and David Lilien, "Social Security and the Retirement Decisions," Quarterly Journal of Economics, Aug. 1981, XCVI, 509-529.

Danziger, Sheldon., Jacques vcan der Gaag, Eugene Smolensky, and Michael Taussig, "The Life Cycle Hypothesis and the Consumption Behavior of the Elderly," Journal of Post Keynesian Economics, 1982.

Danziger, Sheldon, Jacques van der Gaag, Eugene Smolensky and Michael Taussig. "Implications of the Relative Economic Status of the Elderly for Transfer Policy," in Retirement and Economic Behavior. Eds.: H. Aaron and G. Burtless. The Brookings Institution, 1984a.

Danziger, Sheldon, Jacques van der Gaag, Eugene Smolensky and Michael Taussig. "Income Transfers and the Economic Status of the Elderly," in Economic Transfers in the United States. Ed.: Marilyn Moon. The National Bureau of Economic Research, $1984 \mathrm{~b}$.

Darby, Michael R. Effects of Social Security on Income and the Capital Stock. Wash., D.C.: Amer. Ent. Inst., 1979.

Davies, James B. "Uncertain Lifetime, Consumption, and Dissaving in retirement," Journal of Political Ecconomy 1981, vol. 89, no. 31, pp.561-576.

Diamond, Peter A. "Comment on The Economics of Saving: A Survey of Recent Contributions." in Frontiers of Economics, Eds: K. Arrow and S. Harkapohja, Oxford: Basil Blackwell, 1985, pp 295-306.

Diamond, Peter A. and Hausman, Jerry A. "The Retirement and Unemployment Behavior of Older Men," in Retirement and economic behavior. Eds.: Henry J. Aaron and Gary Burtless. Washington, D.C.: The Brookings Institution, 1984 a.

Diamond, Peter A. and Jerry Hausman. "Individual Retirement and Savings Behavior." Journal of Public Economics, February/March 1984b, 23, Pp 81-114.

Duesenberry, James, Income, Saving and the Theory of consumer Behavior, Cambridge: Havard University Press, 1949

Ellwood, David T., "Pensions and the Labor Market: A Starting Point (The Mouse Can Roar)," in Pensions, labor, and individual choice, Ed.: David A. Wise. Chicago: The University of Chicago Press, 1985.

Feinstein, Jonathan, and Daniel MaFadden. "The Dynamics of Housing Demand by the Elderly: Wealth, Cash Flow, and Demographic Effects," in The Economics of Aging. Ed: D. Wise, Chicago: The University of Chicago Press, 1989. 
Feinstein, Jonathan and Daniel L. McFadden. "The Dynamics of Housing Demand by the Elderly: User Cost Effects," NBER Conference on the Issues in the Economics of Aging, Phoenix, AZ, May 1988.

Feldstein, Martin, "Social Security, Induced Retirement and Aggregate Capital Formation." Journal of Political Economy, June 1974, 82, pp 905-926.

Flavin, Marjorie, "The Adjustment of Consumption to Changing Expectations about Future Income." Journal of Political Economy, 1981, 89, pp 974-1009.

Friedman, Benjamin M. and Warshawsky, Mark. "Annuity Prices and Saving Behavior in the United States," in Penstons in the U.S, economy, Eds.: Zvi Bodie, John B. Shoven and David A. Wise. Chicago, Univ.: National Bureau of Economics Research, Inc. 1988 .

Fuchs, Victor R. "Time Preference and Health: An Exploratory Study," in Economic Aspects of Health. Ed: Victor Fuchs, Chicago: University of Chicago Press, 1982 .

Fuchs, Victor R. "Self-Employment and Labor Force participation of Older Males," The Journal of Human Resources. Summer 1982, Vol.XVII, No.3, pp. $339-357$.

Fuchs, Victor $R$. "Though Much Is Taken: Reflections on Aging, Health, and Medical Care," Milbank Memorial Eund Quarterly, Spring, 1984, 62, pp 143-166.

Gordon, Roger and Alan Blinder, "Market Wages, Reservation Wages and Retirement," J, of Public Economics, 14, 1980, pp 277-308.

Gustman, Alan L. and Thomas L. Steinmeier. "Partial Retirement and the Analysis of Retirement Behavior," Industrial and Labor Relations Review, April 1984, Vol. 37. No. 3, pp. 403-415.

Gustman, Alan L. and Thomas L, Steinmeier. "The Effect of Partial Retirement on the Wage Profiles of Older Workers," Induscrlal Relations, Spring 1985, Vol.24, No. 2, pp. $257-265$.

Gustman, Alan and Thomas L. Steinmeier. "A Structural Retirement Model," Econometrica, May 1986, Vol.54, No.3, pp. 555-584.

Hall, Robert E. "Stochastic Implications of the Life Cycle-Permanent Income Hypothesis: Theory and Evidence." Journal of Political Economy, 1978, 86, pp 971-987.

Hamermesh, Daniel S. "Consumption During Retirement: The Missing Link in the Life Cycle," Review of Economics and Statistics. February 1984, Vol. $\underline{66}$, No.1, pp. $1-7$.

Hanoch, Giora and Marjorie Honig, "Retirement, Wages and Labor Supply of the Elderly," April, 1983, Journal of Labor Economics, 1, pp 131-151.

Hausman, Jerry A. and Wise, David A. "Discontinuous Budget Constraints and Estimation: The Demand for Housing," The Review of Economic studies, 1980 , XLVII, pp 75096.

Hausman, Jerry A. and Wise, David A. "Social Security, Health Status, and 
Retirement," in Pensions, labor, and individual choice, Ed.: David A. Wise. Chicago, Univ.: National Bureau of Economics Research, Inc. 1985.

Haveman, Robert, Barbara Wolfe and Jennifer Warlick, "Disability Transfers, Early Retirement, and Retrenchment," in Retirement and Economic Behavior. Eds.: Henry J. Aaron and Gary Burtless. Washington, D.C.: The Brookings Institution, 1984 .

Hayashi, Fumio, "The Permanent Income Hypothesis: Estimation and Testing by Instrumental Variables." Journal of Polftical Economy, October 1982, 90, pp $895-918$.

Henderson, J. Vernon, and Yannis M. Ioannides, "A Model of Housing Tenure Choice," American Economic Review, March 1983, 73, pp 98-113.

Holden, Karen, "Living Arrangements, Income and Poverty of 01der Women in the U.S., 1950-1980," Institute for Research on Poverty Discussion Paper 804-86, 1986

Holden, Karen. "Poverty and Living Arrangements Among Older Women: Are Changes

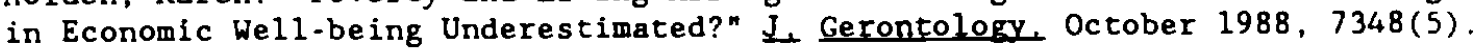

Holden, Karen, Richard Burkhauser and Daniel J. Feaster. "The Timing of Falls into Poverty after Retirement: an Event-History Approach," Demography.

Holden, Karen, Richard V. Burkhauser and Daniel Myers. "Income Transitions at Older Stages of Life: the Dynamics of Poverty," The Gerontologist. 1986, Vo1.26, No. 3, pp. $292-297$.

Honig, Marjorie "Partial Retirement among Women," Journal of Human Resources, Fal1 1985, 20, pp 613-621.

Hurd, Michael D. "Savings of the Elderly and Desired Bequests," The American Economic Review, June 1987a, Vol. 77, No.3, pp. 298-312.

Hurd, Michael D "The Marginal Value of Social Security." NBER Working Paper 2411, $1987 \mathrm{~b}$.

Hurd, Michael D. "The Joint Retirement Behavior of Husbands and Wives," presented at the NBER conference on the Economics of Aging. Phoenix, May, 1988.

Hurd, Michael D. Mortality Risk and Bequests, forthcoming, 1989, Econometrica

Hurd, Michael D. and Michael J. Boskin. "The Effect of Social Security on Retirement in the Early 1970s," Quarterly Journal of Economics, November 1984, pp. $767-790$.

Hurd, Michael D. and B. Gabriela Mundaca. "The Importance of Gifts and Inheritances Among the Affluent," in The Measurement of Saving. Investment and Wealth, Eds: Robert E. Lipsey and Helen Stone Tice, Chicago: University of Chicago Press, forthcoming 1989.

Hurd, Michael D. and John B. Shoven. "Real Income and Wealth of the Elderly," The American Economic Review, May 1982, Vol.12, No.2, pp. 314-318. 
Hurd, Michael D. and John B. Shoven. "The Economic Status of the Elderly," in Financial aspects of the U.S, pension system, Eds.: Zvi:Bodie and John B. Shoven. Chicago: The University of Chicago Press, 1984.

Hurd, Michael D. and John B. Shoven. "The Distributional Impact of Social Security," in Pensions, labor and individual cholce, Ed.: David A. Wise. Chicago: The University of Chicago Press, 1985.

Hurd, Michael D. and John B. Shoven. "Inflation Vulnerability, Income, and Wealth of the Elderly, 1969-1979," in Horizontal equity uncertainty and economic well-being. Eds.: Martin David and Timothy Smeeding. Chicago: The University of Chicago Press, 1985.

Hurd, Michael D. and David A. Wise. "The Wealth and Poverty of Widows: Assets Before and After the Husband's Death," in The Economics of Aging, Ed: D. Wise, Chicago: The University of Chicago Press, 1989.

Jianakoplos, Nancy A., Paul L. Menchik and F. Owen Irvine. "Using Panel Data to Assess the Bias in Cross-Sectional Inference of Life-Cycle Changes in the Level and Composition of Household Wealth," in The Measurement of Saving. Investment and Wealth, Eds: Robert E. Lipsey and Helen Stone Tice, Chicago: University of Chicago Press, forthcoming 1989.

King, Mervyn, "The Economics of Saving: A Survey of Recent Contributions." in Frontiers of Economics, Eds: K. Arrow and S. Harkapohja, Oxford: Basil

Blackwel1, 1985, pp 227-294.

King, Mervyn and L. Dicks-Mireaux "Asset Holdings and the Life-Cycle." The Economic Journal, June 1982, 92, pp 247-267.

Kotlikoff, Laurence J. and John Morris. "How Much Care Do the Aged Receive Fror their Children? A Bimodal Picture of Contact and Assistance," in The Economics of Aging, Ed: D. Wise, Chicago: The University of Chicago Press, 1989.

Kotlikoff, Lawrence J., John Shoven, and Avia Spivak. "The Effect of Annuity Insurance on Savings and Inequality," Journal of Labor Economics. July 1986, Vol. 4, No.3, Part 2.

Kotlikoff, Laurence J., John B. Shoven and Avia Spivak. "Annuity Markets, Savings, and the Capital Stock," in Issues in Pension Economics. Eds.: Zvi Bodic John B. Shoven, and David A. Wise. Chicago: The University of Chicago Press, 1987.

Kotlikoff, Laurence J. and Avia Spivak. "The Family as an Incomplete Annuitie: Market." Journal of Political Economy. April 1981, 89, pp 372-391.

Kotlikoff, Laurence J., Avia Spivak, and Lawrence Summers. "The Adequacy of Savings," The American Economic Review, December 1982, Vol. 72, No.5, pp.10561069 .

Kotlikoff, Laurence J. and Lawrence Summers "The Role of Intergenerational Transfers in Aggregate Capital Accumulation." Journal of political Economy, August 1981,89 , PP $706-732$.

Kotlikoff, Laurence J, and Lawrence Summers, "The Contribution of 
Intergenerational Transfers to Total Wealth: A Reply, " in Modelling the Accumulation and Distribution of Wealth, Eds: Denis Kessler and Andre Masson, New York: Oxford University Press, 1988, pp 53-67

Kotlikoff, Laurence J. and David A. Wise. "Pension Backloading, Wage Taxes, and Work Disincentives," NBER Working Paper Serles, 1987a, Working Paper No. 2463.

Kotlikoff, Laurence J. and Wise, David A. "The Incentive Effects of Private Pension Plans," in Issues in pension economics. Eds.: Zvi Bodie, John B. Shoven and David A. Wise. Chicago, Univ.: National Bureau of Economics Research, Inc. $1987 \mathrm{~b}$.

Kotlikoff, Laurence J. and David A. Wise. "Employee Retirement and A Firm's Pension Plan," in The Economics of Aging, Ed: D. Wise, Chicago: The University of Chicago Press, 1989.

Krueger, Alan and Jorn-Steffen Pischke, "The Effect of Social Security on Labor Supply: A Cohort analysis of the Notch Generation, "presented at the NBER Conference on Social Insurance, Cambridge, MA, 1989.

Kurz, Mordecai, "Heterogeneity in Savings Behavior: A Comment." in Frontiers of Economics, Eds: K. Arrow and S. Harkapohja, Oxford: Basil Blackwell, 1985, PP 307-327.

Lazear, Edward and Robert Moore, "Pensions and Turnover," in Eds: Z. Bodie, J. Shoven and D. Wise, Pensions in the U,S. Economy, Chicago: The University of Chicago Press, 1988.

Lydal1, Harold, "The Life Cycle, Income, Saving, and Asset Ownership," Econometrica, April 1955, 23, pp 985-1012.

McDermed, Ann, Robert Clark and Steven Allen. "Pension Wealth, Age-Wealth Profiles, and the Distribution of Net Worth," Department of Economics, North Carolina State University, Faculty Working Paper No. 105, 1987.

Menchik, Paul L. and Martin David. "Income Dlstrlbution, Lifetime Savings, and Bequests," American Economic Review, September 1983, Vol.73, No.4, pp. 672-690

Merrill, Sally R. "Home Equity and the Elderly," in Retirement and economic behavior. Eds.: Henry J. Aaron and Gary Burtless. Washington, D.C.: The Brookings Institution, 1984.

Michael, Robert T., Fuchs, Victor R. and Scott, Sharon R. "Changes in the Propersity to Live Alone, 1950-1976," Demography, February 1980, vol.17, pp3956.

Mirer, Thad, "The Wealth-Age Relation Among the Aged." American Economic Review, June 1979, 69, pp 435-443.

Mirer, Thad, "The Dissaving Behavior of the Retired Aged," Southern Economic Journal, April 1980, 46 (4) pp 1197-1205.

Modigliani, Franco. "Life Cycle, Individual Thrift, and the Wealth of Nations." American Economic Review, June 1986, 76, (3) pp 297-313. 
Mitche11, 01 ivia S, and Gary S. Fields. "The effects of Pensions and Earnings on Retirement: A Review Essay," in Research in labor Economics, Vol 5, Ed: Ron Ehrenberg, Greenwich: JAI Press, 1982, PP 115-155.

Mitche1l, Olivia S, and Gary S. Fields, "Econonomic Incentives to Retire: A Qualitiative Choice Approach," 1983, NBER Working Paper 1096.

Mitche11, 0livia S. and Fields, Gary S. "Rewards for Continued Work: The Economic Incentive for Postponing Retirement, " in Horizontal Equity.

Uncertainty, and Economic Wel1-Being, Eds.: Martin David and Timothy Smeeding. Chicago, Univ.: National Bureau of Economics Research, Inc. 1985.

Moffitt, Robert. "Trends in Social Security Wealth by Cohort," in Economic Transfers in the United States. Ed.: Martin Moon. Chicago: The University of Chicago Press, 1984.

Moffitt, Robert A. "Life-Cycle Labor Supply and Social Security: A Time-Series Analysis," in Work Health and Income among the Elderly, G. Burtless, ed., Washington: The Brookings Institution, 1987, pp.183-228.

Myers, Daniel A., Richard V. Burkhauser and Karen C. Holden. "The Transition from Wife to Widow: the Importance of Survivor Benefits to the Well-Being of Widows," IRP Discussion Papers, April 1986, DP \#806-86.

Palmer, John, Timothy Smeeding and Christopher Jencks, "The Uses and Limits of Income Comparisons," in The Vulnerable, Eds: John Palmer, Timothy Smeeding and Barbara Boyle Torrey, Washington: The Urban Institute Press, 1988, 9-28.

Parsons, Donald, "The Decline in Male Labor Force Participation, Journal of Political Economy, 1980, 88 (February) 117-134

Poterba, James N. "Comment on Aging, Moving and Housing Wealth," in The Economics of Aging, Ed: D. Wise, Chicago: The University of Chicago Press, 1989.

Pozzebon, Silvana and 0livia S. Mitchell. "Married Women's Retirement Behavior," NBER Working Paper Series, December 1986, Working Paper No. 2104.

Projector, Dorothy, Survey of Changes in Family Finances, Washington: Board of Governors, Federal Reserve Board, 1968.

Projector, Dorothy and Gertrude Weiss, Survey of Einancial Characteristics of Consumers, Washington: Board of Governors, Federal Reserve Board, 1966.

Quinn, Joseph, The Economic Status of the Elderly: Beware of the Mean, $\underline{\text { Review }}$ of Income and Wealth, 1987, 32, no. 4 (March), PP 63-82.

Radner, Daniel, Adjusted Estimates of the Size Distribution of Family Money Income, Journal of Business and Economic Statistics, 1983, 1 (Apri1), pp 135146.

Radner, Daniel, "Changes in the Money Income of the Aged and Nonaged, 1967. $1983, "$ U.S. Department of Health and Human Services, 1986.

Radner, Danie1, Money Incomes of Aged and Nonaged Family Units, 1967-84, Social 
Security Bulletin, 1987a, Vol. 50, No. 8 (August) pp. 9-28.

Radner, Daniel B. "The Wealth of the Aged and Nonaged, 1984," in The Measurement of Saving. Investment and Wealth. Eds: Robert $E$. Lipsey and Helen Stone Tice, Chicago: University of Chicago Press, forthcoming 1989.

Ross, Christine, Sheldon Danziger and Eugene Smolensky. "Interpreting Changes in the Economic Status of the Elderly, 1949-1979," Contemporary policy Issues. April 1987, Vol.‥ No.2, pp. 98-112.

Rust, John. "Behavior of Male Workers at the End of the Life-Cycle: An Empirical Analysis of States and Controls," presented at the NBER Conference on Aging, Phoenix, 1988

Schwartz, Saul, Danziger, Sheldon and Smolensky, Eugene. "The Choice of Living Arrangements by the Elderly," in Retirement and economic behavior. Eds.: Henry $\mathrm{J}$. Aaron and Gary Burtless. Washington, D.C.: The Brookings Institution, 1984.

Shorrocks, A.F. "The Age-Wealth Relationship: A Cross-Section and Cohort Analysis," Review of Economics and Statistics, May 1975, LVII, (2) Pp 155-163.

Skinner, Jonathan. "Variable Lifespan and the Intertemporal Elasticity of Consumption," The Review of Economics and Statistics. 1985, pp.616-623.

Smeeding, Timothy M. "Alternative Methods for Valuing Selected In-Kind Transfer Benefits and Measuring Their Effect on Poverty," Technical Paper 50 March 1982.

Smeeding, Timothy. "Full Income Estimates of the Relative Well-Being of the Elderly and the Nonelderly, in Eds: D. Bloom and D. Slottje, Research in Economic Inequality, Vol 1. Greenwich: JAI Press, forthcoming 1989.

Stahl, Konrad, "Housing Patterns and Mobility of the Aged: The United States and West Germany," in The Economics of Aging, Ed: D. Wise, Chicago: The University of Chicago Press, 1989.

Stock, James H. and David A. Wise. "The Pension Inducement to Retire: An Option Value Analysis," NBER Working Paper 2686, 1988

Thompson, Lawrence, "The Social Security Reform Debate," Journal of Economic Literature, December, 1983, XXI, pp 1425-1467.

U.S. House of Representatives Committee on Ways and Means, "Retirement Income for an Aging Population," U.S. Government Printing Office, 1987.

U.S. Senate Special Committee on Aging, Aging America, 1987-88 Edition,

U.S.Department of Health and Human Services, 1988.

van der Gaag, Jacques and Eugene Smolensky, "True Household Equivalence Scales and Characteristics of the Poor in the U.S." Review of Income and Wealth, 1982, 28 (March) pp 17-28.

Venti, Steven F. and David A. Wise. "Aging, Moving and Housing Wealth," in The Economics of Aging Ed: D. Wise. Chicago: The University of Chicago Press, 1989.

Weinrobe, Maurice D. "Home Equity Conversion by the Elderly in the United 
States. An Examination of the Initial Experience," September 1984a, mimeo, National Center for Home Equity Conversion.

Weinrobe, Maurice D. "HELP Comes to Buffalo: A Review and Analysis of the Initial Equity Conversion Experience," December, 1984b, mimeo, National Center for Home Equity Conversion.

White, Betsy Buttrill. "Empirical Tests of the Life-Cycle Hypothesis," American Economic Review, Sept. 1978, 68(4), pp. 547-560.

Wolff, Edward N. "Social Security, Pensions and the Life cycle Accumulation of WEalth: Some Empirical Tests," Annales D'Economie et de Statistique, Jan/Mar 1988 , 9, pp $199-226$.

Yaari, Menahem E. "Uncertain Lifetime, Life Insurance and the Theory of the Consumer," Review of Economic Studies, 1965, 32, pp 137-150. 
</ref_section> 